\title{
Prediction, Synthesis and Evaluation of an Antimicrobial Peptide from Goat Vitronectin (Vn)
}

\author{
Prasanta Kumar Koustasa Mishra*, Aditya Agrawal, Anil Gattani and Yapu Nijo
}

Division of Biochemistry, Indian Veterinary Research Institute, Bareilly, UP-243122, India

*Corresponding author

\begin{tabular}{|c|c|}
\hline & A B S T R A C T \\
\hline $\begin{array}{l}\text { Antimicrobial } \\
\text { peptide, Vitronectin, } \\
\text { Escherichia coli } \\
\text { DH5- } \alpha, \text { MBC, }\end{array}$ & \multirow{3}{*}{$\begin{array}{l}\text { Antimicrobial resistance is an emerging challenge for health personnel and researchers. In } \\
\text { such scenario, alternative strategies targeting novel ways to kill or inhibit growth of } \\
\text { microbes are need of the hour. Antimicrobial peptide can be a promising candidate to deal } \\
\text { with this crisis. Extracellular matrix protein vitronectin (Vn) is recently being established } \\
\text { as a bactericidal agent against certain microbes. Caprine Vn has got few structural } \\
\text { alterations as compare to human Vn. Here we have applied bioinformatics approaches to } \\
\text { screen as well as characterise regions of goat Vn having antimicrobial peptide followed by } \\
\text { synthesis of a predicted peptide and evaluation of the antimicrobial effect of the same } \\
\text { against Escherichia coli DH5- } \alpha \text { cells. The minimum bactericidal concentration (MBC) was } \\
\text { determined by resazurin reduction test (RRT) and found to be } 250 \mu \mathrm{g} / 10^{7} \text { E. coli cells. } \\
\text { The peptide gave visible inhibition against the test organism. }\end{array}$} \\
\hline Article Info & \\
\hline $\begin{array}{l}\text { Accepted: } \\
\text { 10 June } 2018 \\
\text { Available Online: } \\
\text { 10 July } 2018\end{array}$ & \\
\hline
\end{tabular}

\section{Introduction}

Antimicrobial peptides (AMPs) can be defined as a large number of small proteins (peptides) that can kill or inhibit the growth of various microbes. The peptides can be of varied length starting from 6 to 50 amino acids (Zasloff $e t$ $a l ., 2002)$ or maximum upto 100 residues (Xiao et al., 2015). In case of mammals, the AMPs can be categorized under three classes as defensin, cathelicidines and histatin (Smet and Contreras, 2005). AMPs can be divided into various classes based on their structure, function and mode of action. Structure based classification categorizes AMPs as $\alpha$ helix forming, $\beta$ sheet forming, loop former and extended conformations (Huang et al., 2010). Functionally, they can be again classified as anti-viral, anti-bacterial, anti-fungal and antiparasitic. According to mechanism of action, they are grouped under two categories: (i) membrane acting and (ii) non-membrane acting. In mammals, the AMPs are distributed throughout different cell types and tissues such as neutrophils, epithelial cells, mesenchymal tissues, articular cartilage and mucosal epithelial cells (Zasloff et al., 2002). Recent evidences suggest extracellular matrix protein vitronectin $(\mathrm{Vn})$ is capable of killing bacteria. The HBD-3 of Vn has structural similarity to HBDs of AMP like LL-37 and $\alpha-$ defensin (Schimdtchen et al., 2001). The 
Cardin motif in HBD-3 of Vn was bactericidal towards Enterococcus faecalis. Though the mechanism of Vn mediated bacterial killing is not clear (Singh et al., 2011) but at low salt concentration the killing effect of HBD-3 was higher towards E. coli, Candida albicans and Proteus mirabilis. In the present study we have predicted the stretch(es) of goat $\mathrm{Vn}$ which can act as potential AMP.

\section{Materials and Methods}

Retrieval of caprine Vn sequence and prediction of AMP

The caprine $\mathrm{Vn}$ sequence is available in uniProt with uniProt ID Q3LRQ1 (Q3LRQ1_CAPHI). The sequence was retrieved and was analysed in an online based free server AMPA( http://tcoffee.crg.cat/apps/ampa/do). Default parameters provided by the server were used for identification of potential regions of $\mathrm{Vn}$ with AMP activity (Fig. 1).

\section{Determination of biochemical properties of predicted peptides}

The outputs of AMPA server were further analysed in Swiss Prot's proto-param module available online at free accession (https://web.expasy.org/cgi-bin/protparam/ protparam). The overall hydropathicity (GRAVY) values were compared and calculated (Table 1).

\section{Synthesis of selected peptide}

The chosen peptide on the basis of hydropathicity was synthesized following 9fluorenylmethoxycarbonyl (fMoc) chemistry described by Merrifield (Merrifield, 1963). Coupling reagents 1-hydroxy benztriazole (HoBT) was purchased from Orpegen pharma (Germany), 2-(1H-benzotriazolyl-1-yl)1,1,3,3-tetramethlyuronium hexafluoro phosphate (HBTU) was procured from GL Biochem (Shanghai, China) and Nova Biochem (Switzerland).The peptide was finally resuspended in HPLC grade water at a final concentration of $25 \mathrm{mg} / \mathrm{ml}$.

\section{Dot blot analysis of the peptide}

The peptide was confirmed by immobilising $5 \mu \mathrm{g}$ of peptide on a nitrocellulose membrane followed by incubation with rabbit anti-goat $\mathrm{Vn}$ at 1:250 dilutions in PBST and using horse reddish peroxidase(HRPO) conjugated goat anti-rabbit antibody (GeNei, Bangalore, India) at 1:500 dilutions. The blot was developed by HRPO catalysed oxidation of diamino benzidine (DAB)(Sigma-Aldrich) as substrate. $\mathrm{Vn}, \mathrm{N}$ - and C-domain of Vn were also blotted to the membrane and served as positive control whereas HPLC grade water served negative control (Fig. 2).

\section{Circular dichroism(CD) spectroscopy}

$200 \mu \mathrm{l}$ of peptide $(250 \mu \mathrm{g} / \mathrm{ml})$ was subjected to spectropolarimetric analysis in Jasco-180 CD spectrophotometer available at central instrumentation facility (CIF), IVRI. The data recorded were average of four scans performed from 190-310 $\mathrm{nm}$. The response is presented as ellipticity in millidegree (Fig. 3). Structural details about the secondary structure of peptide were outputs of Jasco-720 software (Table 2).

\section{Resazurin reduction test (RRT)}

Reduction of resazurin to resorufin by live bacteria was proposed by Moyer and Campbell in 1963. Here we have used RRT to assess the minimum bactericidal concentration (MBC) of the peptide. E coli DH5- $\alpha$ cells were used as test organisms for the assay.

Briefly, to a 96 well polystyrene microtitre plate (Nunc MaxiSorp ${ }^{\mathrm{TM}}$ flat-bottom, Thermo 
Fischer scientific) $100 \mu \mathrm{l}$ of freshly grown E.coli cells $\left(\mathrm{OD}_{600}-0.1\right)$ were transferred in triplicates as three different groups .

The peptide was diluted to three different concentrations in normal saline and $100 \mu \mathrm{l}$ of each dilutions were added to the wells so that the groups received 250, 125 and $62.5 \mu \mathrm{g}$ of peptide respectively. The plate was incubated at $37^{\circ} \mathrm{C} / 1$ hour following a brief period of exposure to $4^{\circ} \mathrm{C}$ in order to avoid endocytosis of the treated peptide. $30 \mu \mathrm{l}$ of $0.1 \%$ resazurin was added to all wells and incubated further for 2 hours at $37^{\circ} \mathrm{C}$. Change in colour of the resazurin solution was visually evaluated (Fig. 4).

\section{Evaluation of antimicrobial effect}

Overnight grown E. coli DH5- cells was subcultured at 1:100 and was grown till it attended $\mathrm{OD}_{600}$ of $0.1 .100 \mu \mathrm{l}$ of culture was removed and was separated from the media by centrifugation at $5000 \mathrm{rpm} / 5$ minutes. The pellet was resuspended with the test peptide so that the pellet received $250 \mu \mathrm{g}$ of total peptide. The bacterial suspension was incubated for an hour at $37^{\circ} \mathrm{C}$ as described in the RRT test. The treated peptide solution was isolated from the bacteria by centrifuging the suspension at $5000 \mathrm{rpm} / 5 \mathrm{mins}$.

The pellet was washed twice with normal saline and finally resuspended in $1 \mathrm{ml}$ of NS. Tenfold serial dilutions of the treated bacteria were prepared in NS and $10 \mu \mathrm{l}$ from dilutions $10^{-3}, 10^{-4,} 10^{-5}, 10^{-6}$ were spotted onto a Luria Bertani (LB) agar (Sisco research laboratory, Mumbai) plate in quadruplicates. Ampicillin $(25 \mu \mathrm{g})$ and NS served as positive and negative control respectively. Controls were prepared similarly as per the peptide and were spotted to two different LB plates. All the three plates were incubated for 16 hours at $37^{\circ}$ $\mathrm{C}$ and the colonies were counted (Fig. 5).

\section{Results and Discussion}

In caprine species, C-domain of $\mathrm{Vn}$ is responsible for binding to Staphylococcus aureus (Mahwar and Joshi, 2008) whereas $\mathrm{N}$ domain of it showed growth inhibition in $E$. coli (Rao et al., 2017).

The 444 amino acid sequence of goat Vn was retrieved from uniProt server and was analysed in AMPA module. Upon analysis the server identified 5 potential stretches in $\mathrm{Vn}$ which might show anti-microbial effect (Fig. 1). Though the propensity of ERVYFFKGNHYW peptide was more to be an antimicrobial agent but as per grand average of hydropathicity (GRAVY) value, peptide MTKSARRHRKRYRSLRSRGRGR GRARSQ and PYRRFRSTWLSW were selected initially. But stability of in vitro synthesized peptides of more than 20 amino acids is a matter of concern (Gentilucci et al., 2010). So the peptide with sequence PYRRFRSTWLSW was opted for synthesis. Dot blot analysis confirmed the synthesized peptide as a representative stretch of goat Vn. The predicted 3D structure of the peptide (http://bioserv.rpbs.univ-paris-diderot.fr/ services/PEP-FOLD/) is of helical contour (Fig. 6). But in contrast to that $\mathrm{CD}$ spectroscopy suggested presence of $\beta$ strand as high as $75.7 \%$ and $24.3 \%$ of random coils which might be due to the cross linked polymeric form of the synthesized peptide. Further, the helical contour may help the peptide in better membrane permeability. Some AMPs like protegrin, maginin, cyclic and coiled indolicidin do belong to $\alpha$ helix forming group whereas defensins are grouped under $\beta$ sheet forming proteins (Huang et al., 2010). The potential of RRT has been already established in determining MIC of antimicrobial agents. 
Table.1 Biochemical properties of the predicted peptides

\begin{tabular}{|l|l|l|l|l|}
\hline Peptide sequence & $\begin{array}{l}\text { Number } \\
\text { of amino } \\
\text { acids }\end{array}$ & $\begin{array}{l}\text { Molecular } \\
\text { weight in Da }\end{array}$ & $\begin{array}{l}\text { Theoretical } \\
\text { iso electric } \\
\text { pH }\end{array}$ & $\begin{array}{l}\text { Grand average of } \\
\text { hydropathicity } \\
\text { (GRAVY) }\end{array}$ \\
\hline FNCQGKTYLF KGSQYW & 16 & 1970.23 & 9.11 & -0.762 \\
\hline ERVYFFKGNHYW & 12 & 1645.84 & 8.6 & -1.058 \\
\hline $\begin{array}{l}\text { MTKSARRHRKRYRSLRS } \\
\text { RGRGRGRARSQ }\end{array}$ & 28 & 3427.96 & 12.65 & -2.182 \\
\hline PYRRFRSTWLSW & 12 & 1654.89 & 11.71 & -1.158 \\
\hline RVNLRTRRVDSV & 12 & 1470.70 & 12.00 & -0.842 \\
\hline
\end{tabular}

Table.2 Secondary structure content of the peptide

\begin{tabular}{|l|l|}
\hline Structure type & Percentage \\
\hline Helix & 0 \\
\hline Beta & 75.7 \\
\hline Turn & 0 \\
\hline Random & 24.3 \\
\hline Total & $\mathbf{1 0 0}$ \\
\hline
\end{tabular}

Fig.1 The output of AMPA server against query made for caprine Vn

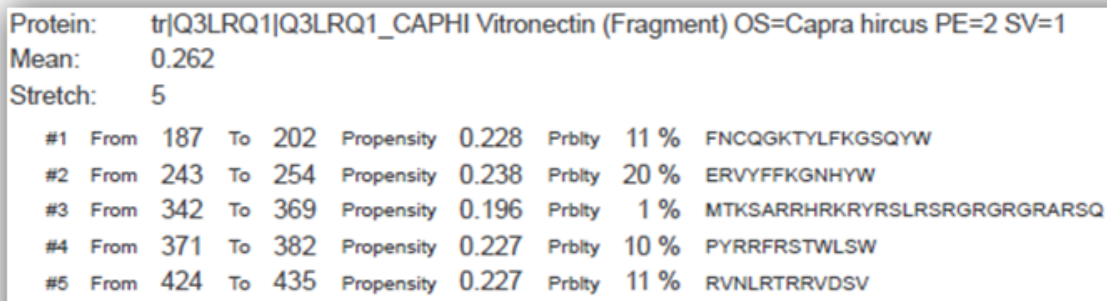

DQESCKGRCTEGFNATRKCQCDELCSYYQSCCADFMAECKPQVTRGDVFHLPEDEYGTYDYGEVQTVNRSVEAQPESPTLAPVLQAEIPVQAPVLNPEKEAPS PGRGDSDPGLGTSDLGTSESPAEEETCSGKPFDAFTDLKNGSLFAFRGLYCYELDEKAVRPGYPKLIRDVWGIEGPIDAAFTRENCOGKTYLFKGSOYWRFED GVLEPDFPRNISDGFKGIPDDVDAALALPAHSYNGRERVYFFKGNHYWEYVFQQQPSREECEGSSQPAAFKHFALMQRDSWEDIFRLLFWGGSFGGAGQPQLI SRDWFGLPGKLDAAMAGHIYISGSAPSSPRAKMTKSARRHRKRYRSLRSRGRGRGRARSQNPYRRERSTWLSWFSSEELGLGADNYDNYEMDWLVPATCEPIO SVYFFSEDKYYRVNLRTRRVDSVIPPYPRSIA

Fig.2 Dot blot showing positive reaction of the peptide with anti-goat Vn

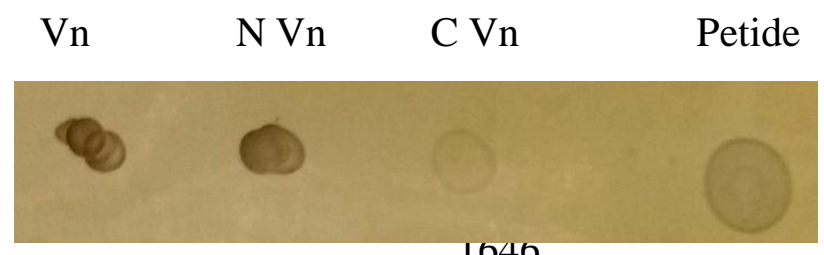


Fig.3 Circular dichroism spectroscopy analysis of the peptide

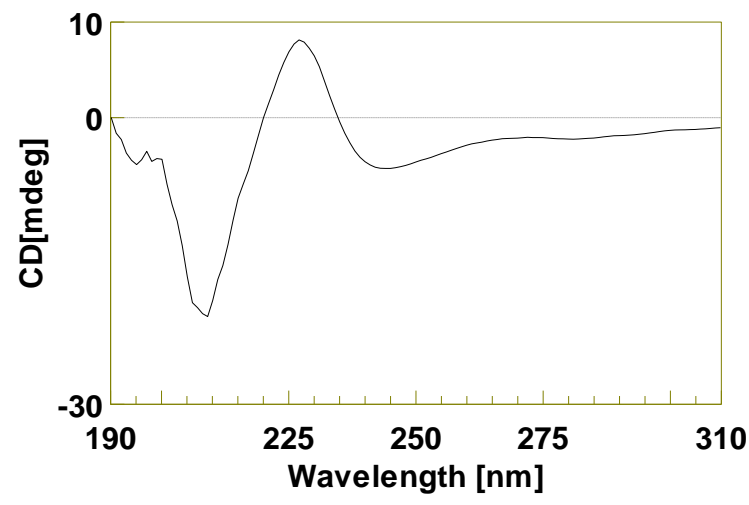

Fig.4 RRT to determine minimum bactericidal concentration of the peptide

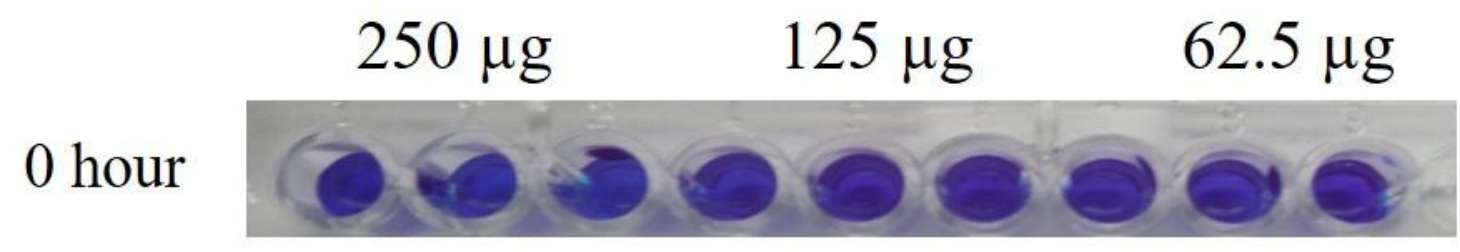

2 hours

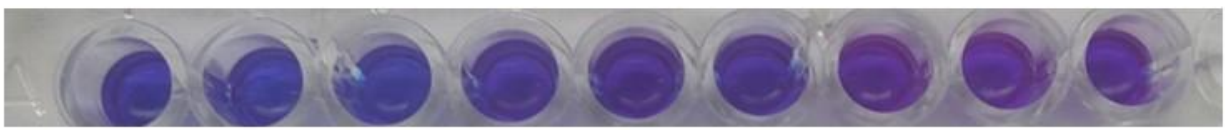

Fig.5 Drop plate method to evaluate efficacy of the peptide

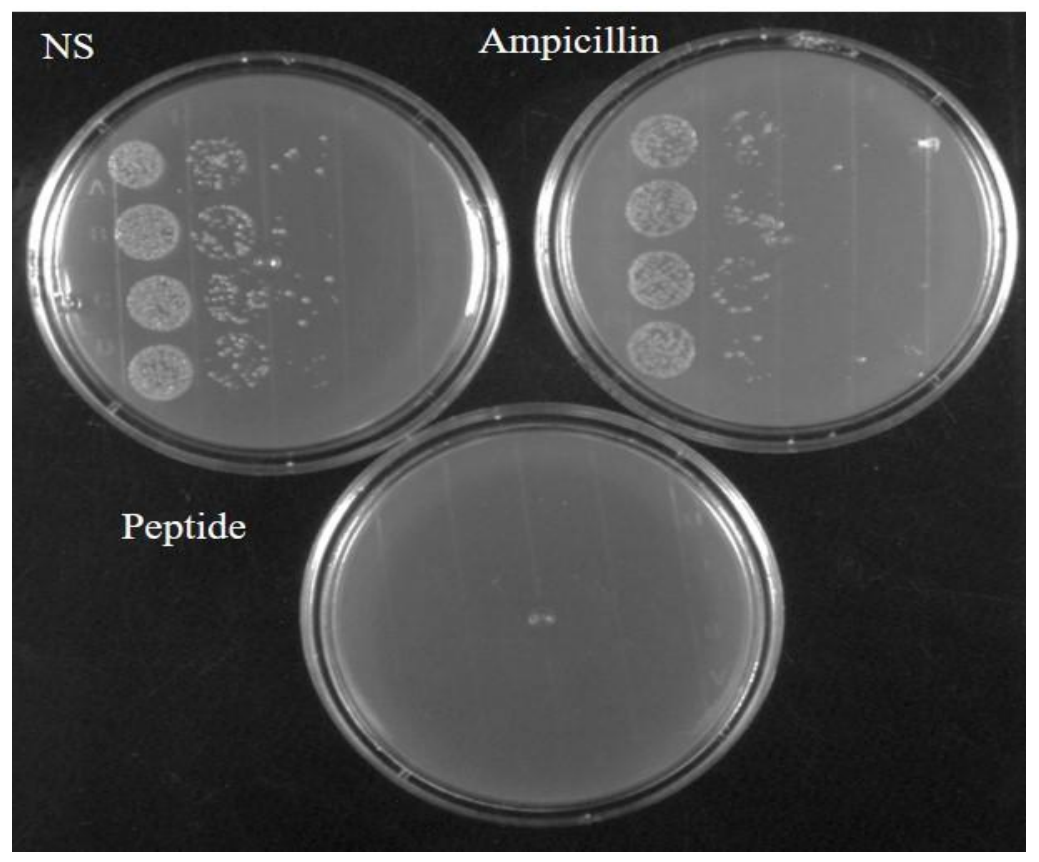


Fig.6 Predicted 3D structure of the peptide

(a) Ball and stick model (b) Cartoon structure
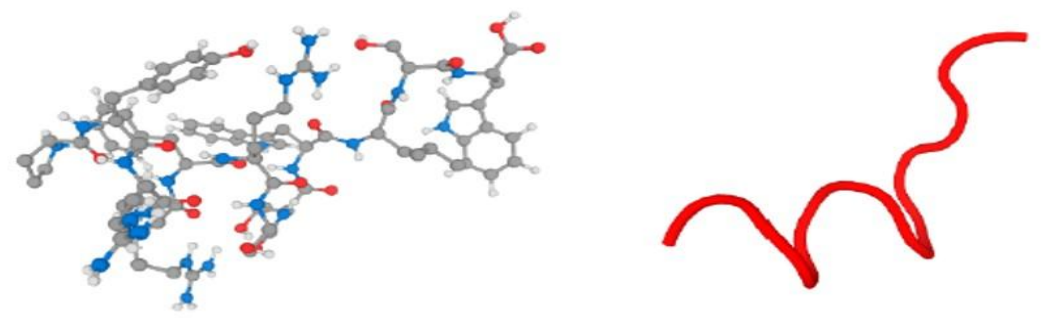

Fig.7 Bacterial lysis visible by caseous clot formation (Indicated by arrow mark)

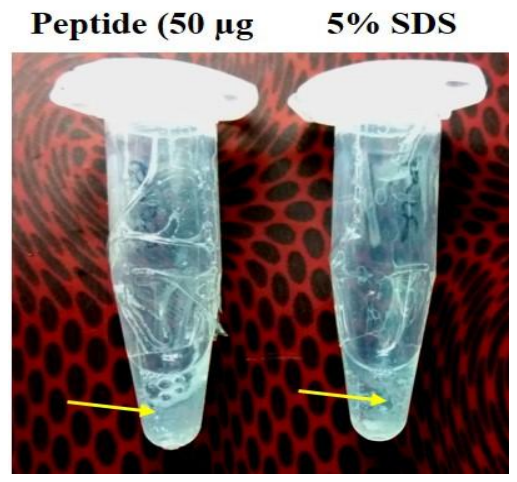

The reduction of resazurin by various dehydrogenases in live bacteria results in formation of pinkish coloured resorufin. But dead bacteria are unable to bring such changes in the reaction medium. The wells with $62.5 \mu \mathrm{g}$ of peptide showed pink colour after incubation with resazurin solution whereas the $125 \mu \mathrm{g}$ wells were slightly purplish. But the colour was relatively unchanged in $250 \mu \mathrm{g}$ peptide treated wells. The MBC of the peptide was taken as 250 $\mu \mathrm{g} / 10^{7}$ DH5- $\alpha$ cells and used in subsequent study. The drop plate method indicated a strong antimicrobial effect of the peptide as there was no growth even at $10^{-3}$ dilutions as compare to ampicillin and NS which had two and eight colonies respectively at $10^{-5}$ dilutions. Decreasing the concentration of peptide to $50 \mu \mathrm{g}$ as a total dose to the same bacterial mass resulted cloudy clots which was comparable to $5 \%$ SDS treated bacterial sample (Fig. 7). Further exploration with higher numbers of replicates and different microbes can help in establishing the antimicrobial potential of this peptide.

The conclusions and future directions are as follows:

Finding newer antimicrobial agents can help in combating the antibiotics resistance strains of microbes. AMP is definitely a potent weapon against such organisms. The peptide identified in the study was found to have potent bactericidal efficacy. Mass spectrometric analysis can help in detailed structural composition of the peptide and testing the peptide against structurally different microbes can explore its range as well as mechanism of action. 


\section{Acknowledgments}

The authors are highly thankful to Director, IVRI and Dr Paritosh Joshi, Principal scientist, Division of Biochemistry for providing necessary funds and facilities. Mishra PKK is supported by ICMR-SRF fellowship, Nijo Y and K.C.Amith by ICARJRF.

\section{References}

Gentilucci, L., De Marco, R., and Cerisoli, L. (2010). Chemical modifications designed to improve peptide stability: incorporation of non-natural amino acids, pseudo-peptide bonds, and cyclization. Current pharmaceutical design, 16(28), 3185-3203.

Huang, Y., Huang, J. and Chen, Y. 2010. Alpha-helical cationic antimicrobial peptides: relationships of structure and function. Protein and cell. 1: 143-152.

Mahawar, M., and Joshi, P. (2008). Goat vitronectin: characterization and binding to Staphylococcus aureus. Comparative Biochem. Physio. Part B: Biochem. Mol.Biol., 149(3), 410-418.

Marc Torrent, Paolo Di Tommaso, David Pulido, M. Victòria Nogués, Cedric Notredame, Ester Boix, David Andreu; AMPA: an automated web server for prediction of protein antimicrobial regions, Bioinformatics, Volume 28, Issue 1, 1 January 2012, Pages 130-131,

Memfield RB. 1963. Solid phase peptide synthesis. I. The synthesis of a tetrapeptide. JAm Chem Soc 8521492154.

Moyer, R. H., and Campbell, J. J. R. (1963). Mechanism of resazurin reduction in milk of low bacterial content. Journal of Dairy Science, 46(9), 897-906.

Prasada, R. T., Lakshmi, P. T., Parvathy, R., Murugavel, S., Karuna, D., and Paritosh, J. (2017). Identification of second arginine- glycine- aspartic acid motif of ovine vitronectin as the complement C9 binding site and its implication in bacterial infection. Microbiol immunol., 61(2), 75-84.

Schmidtchen, A., Frick, I. M. and BjoÈrck, L. 2001. Dermatan sulphate is released by proteinases of common pathogenic bacteria and inactivates antibacterial $\alpha-$ defensin. Mol. Microbial. 39: 708713.

Singh, B., Su, Y. C. and Riesbeck, K. 2011. Vitronectin in host pathogen interactions and antimicrobial therapeutic applications. Centr. Eur. J. Biol. 6: 973-980.

Smet, K. and Contreras, R. 2005. Human antimicrobial peptides: defensins, cathelicidins and histatins. Biotechnol. Lett. 27: 1337-1347.

Xiao, H., Shao, F., Wu, M., Ren, W., Xiong, X., Tan, B. and Yin, Y. 2015. The application of antimicrobial peptides as growth and health promoters for swine. J. Ani Sci. Biotech. 6: 19-26.

Zasloff, M. 2002. Antimicrobial peptides of multicellular organisms. Nature. 415: 389-395.

\section{How to cite this article:}

Prasanta Kumar Koustasa Mishra, Aditya Agrawal, Anil Gattani, Yapu Nijo. 2018. Prediction, Synthesis and Evaluation of an Antimicrobial Peptide from Goat Vitronectin (Vn). Int.J.Curr.Microbiol.App.Sci. 7(07): 1643-1649. doi: https://doi.org/10.20546/ijcmas.2018.707.192 